\title{
Repairing Ecological Processes to Direct Ecosystem State Changes
}

\author{
By Thomas A. Monaco, Chris Call, Merilynn C. Hirsch, and Beth Fowers
}

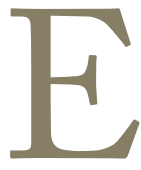

nsuring that rangelands provide a rich array of ecological services into the future will require enduring efforts from research and management professionals. This responsibility is particularly important for those charged with repairing lands impacted by invasive plant species, where attaining success is both difficult and expensive. When ecosystems exist in a degraded invaded state, restoring them to a preexisting state is not likely if foundational ecosystem attributes such as soil and site stability, hydrologic function, and biotic integrity have been drastically altered. It is important for land managers to determine the ecological status of a site prior to implementing restoration treatments. This process-based approach is taking precedence over onesided emphasis on targeting a certain plant community composition because it provides a clear linkage between measurable ecological indicators and ecosystem services sought by a diverse group of stakeholders. ${ }^{1}$ Consequently, management efforts that seek to repair damaged processes or reestablish missing processes must first understand feedback mechanisms operating within an invaded ecosystem state prior to applying restoration strategies.

Ecologically Based Invasive Plant Management (EBIPM) incorporates the need to systematically repair key ecological processes, such that an ecosystem can transition to an alternative state and yield desirable ecosystem services. To assist researchers and managers in the adoption of EBIPM, we first illustrate how the EBIPM framework (see Sheley and Smith, "Ecologically Based Invasive Plant Management: Step by Step," this issue) was used to identify ecological processes within an invaded salt desert shrubland ecosystem and to guide the selection of a management strategy. We then summarize the outcome of how management tools and strategies impacted these processes, provide a descriptive reassessment of the postmanagement state, and discuss ways to refine future restoration activities.

\section{Transitioning to a Seeded Range Ecosystem State in Great Basin Salt Desert Shrublands}

As part of a cooperative management project with landowners and management agencies, we used the EBIPM framework to facilitate a transition from an annual grass invaded state to a seeded range state at two large-scale demonstration salt desert shrubland sites. The overall management objectives were to foster increased livestock forage productivity and reduce wildfire frequency. ${ }^{2}$ Study areas ( $>50$ ha) were in Park Valley, Utah, USA, and are classified as Semidesert Alkali Loam (Black greasewood) (ESD: 028AY202UT; MLRA: 028A). Repetitive fires since the 1980s in this region have led to losses in native grass, forb, and shrub species; broadscale dominance by the invasive annual grass downy brome (Bromus tectorum L.); and the creation of invasive annual grass ecological states (Fig. 1). Although species composition of the current potential state is codominated by the nonsprouting shrub Wyoming big sagebrush (Artemisia tridentata Nutt. ssp. wyomingensis Beetle \& Young) and the fire-tolerant resprouting shrub black greasewood (Sarcobatus vermiculatus [Hook.] Torr.), this state transitions to dominance of the former shrub when fire return intervals are 10-15 years, and to the later shrub when fire return intervals are three-to-five years. Both of these invaded states often exist in plant community phases characterized by nearly complete annual species dominance when wildfire return intervals are less than three years or when seed sources for recolonization by native plant species are no longer present. In addition, these two states have crossed ecological thresholds, making natural recovery to a historical state or to the current potential state unlikely; however, transitioning to a seeded range state, through revegetation using introduced and native perennial grasses, is often sought to increase species diversity, improve forage for livestock, and reduce the size and frequency of wildfires in the region. ${ }^{2}$

\section{EBIPM Step 1: Assess Ecological Processes}

Understanding the dynamics of an ecological site, ${ }^{i}$ defining its ecological state, and recognizing its potential responsiveness to management are critical precursors to initiating a restoration project. However, often understanding of the feedback mechanisms among ecological processes at various

\footnotetext{
See USDA-NRCS Ecological Site Description (ESD) website at http:// esis.sc.egov.usda.gov.
} 


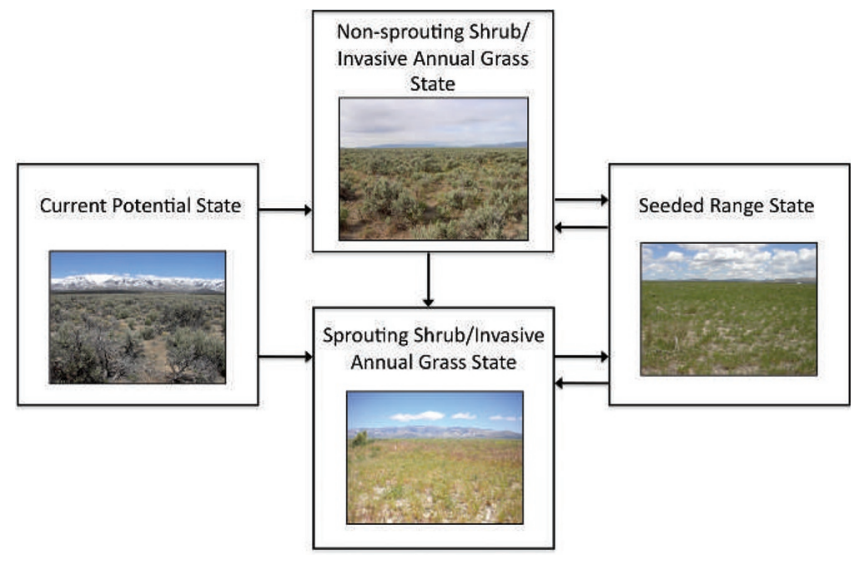

Figure 1. Simplified state-and-transition model for Semidesert Alkali Loam (Black greasewood); Ecological Site Number: 028AY202UT; MLRA: 28A. Boxes represent alternative stable ecosystem states; arrows represent potential transitions.

temporal and spatial scales is limited, and not all processes can be directly impacted with specific management activities to alter resilience mechanisms of an undesirable ecosystem state. Consequently, only a few "keystone" processes are likely to be sufficiently understood. Completing a rangeland health assessment, according to Step 1 of EBIPM, is thus critical because it provides a qualitative understanding of ecological processes and foundational ecosystem attributes of the invaded ecosystem state ${ }^{1,3}$ as well as valuable information regarding the ecological dynamics of potential alternative ecosystem states. $^{4}$

Sites were first monitored in 2009 using the rangeland health assessment protocol as outlined in Step 1 of the EBIPM framework. Also in 2009, we monitored soil nutrient status and soil surface attributes ${ }^{5}$ as well as seed bank composition and vegetation attributes ${ }^{6}$ in small plots distributed across each site. We also gained historical and ecological perspectives of potential constraints of transitioning to a seeded range state by visiting numerous sites with landowners and management personnel who had conducted projects with similar management goals to ours in the past. ${ }^{2}$

\section{EBIPM Step 2: Identify Causes of Invasion and Associated Processes Not Functioning}

Information from Step 1 was then integrated with successional management, as outlined in Step 2 of the EBIPM framework, in order to clarify and prioritize which processes are most in need of repair and how feedback mechanisms are likely responsible for continued dominance by invasive plants. ${ }^{7}$ In this step, keystone processes are characterized according to how they affect the three primary causes of plant community change: site availability, species availability, and species performance. ${ }^{7,8}$ After keystone processes have been prioritized, they can be used to customize an existing state-and-transition model (STM), which is a graphical/textual description of possible soil:vegetation states and transitions for a given restoration site. ${ }^{4}$ When all the elements in Steps 1 and 2 of the EBIPM framework are used together, they function metaphorically similar to a map (ecological site description) and compass (STM) when delineating a course of travel (restoration pathway to an alternative desired ecosystem state).

\section{EBIPM Step 3: Use Principles to Guide Decision Making}

From Steps 1 and 2, we identified that disturbance, dispersal, reproduction, resource acquisition, stress, and interference were processes in need of repair (Fig. 2). For Step 3 of the EBIPM framework, we employed the following ecological principles to guide the design of a restoration plan: 1) lower intensity/frequency disturbance favors the establishment of desired species compared to their higher intensity/frequency alternatives; 2) increasing the dispersal frequency of desired species and decreasing the dispersal frequency of undesired species can allow plant communities to change in a favorable direction; and 3) resources available to an invasive grass can be minimized by establishing desired species that are functionally similar to the invasive grass. ${ }^{9}$

\section{EBIPM Step 4: Choose Appropriate Tools and} Strategies Based on Principles

In Step 4 of the EBIPM framework, we determined that the desired ecosystem transition would require the following restoration tools and strategies: 1 ) impact site availability in fall 2009 using prescribed fire to consume dispersed downy brome seeds and reduce soil-surface litter that is known to facilitate downy brome recolonization and increase the threat of wildfire; 2) impact species availability by applying preemergence herbicide (imazapic) in late fall 2009 to diminish downy brome emergence, biomass production, and reproduction; and 3) impact species performance by revegetating sites with perennial grasses with a late fall 2009 seeding to acquire soil resources, stress downy brome, and interfere with its productivity (Fig. 2). Seeded grasses included bluebunch wheatgrass (Pseudoroegneria spicata [Pursh] Á. Löve), thickspike wheatgrass (Elymus lanceolatus [Scribn. \& J. G. Sm.] Gould), Siberian wheatgrass (Agropyron fragile [Roth] P. Candargy), crested wheatgrass (Agropyron cristatum [L.] Gaertn.), and Russian wildrye (Psathyrostachys juncea [Fisch.] Nevski).

Initial outcome of management tools and strategies. In the first year after applying management treatments (2010), burning and herbicide, especially when combined, effectively reduced soil surface litter, downy brome seed banks, and downy brome cover. ${ }^{6}$ During the same timeframe, soil nitrogen and water availability, measured from April to June, increased in treated areas, and perennial grasses successfully established at a density of two to four plants per square meter. ${ }^{5,6}$ These results were promising and suggested that the reintroduction of an important plant functional group capable of competing with downy brome (i.e., perennial grasses) may lead to future impacts on soil properties and hydrological processes. For example, if perennial grasses steadily gain dominance in the ecosystem, it 
is possible that fuel continuity and fire frequency will decline while the distinctly different life history strategy of perennial grasses will more effectively utilize available soil resources and prolong the period of forage production beyond the narrow period of time typical of the annual grass ecosystem state.

In the second and third year after applying treatments (2010-2011), the abundance of downy brome increased due to above average spring precipitation and generally cooler summer growing conditions. In contrast, during the fourth year after treatment (2012), extremely low precipitation and above average summer air temperatures led to nearly no production from downy brome. Under these dry conditions, both sites were considered at risk for wildfire due to the fine fuel loads created in the two previous years. Consequently, a greenstrip consisting of fire-tolerant perennial species was installed adjacent to one of the sites in the third year, and livestock grazing was initiated at both sites in early spring of the fourth year to reduce wildfire threats and fuel loads, respectively.

\section{EBIPM Step 5: Design and Execute a Plan Using Adaptive Management}

According to Step 5 of the EBIPM framework, the eight steps of adaptive management (see Leffler and Sheley, "Adaptive Management in EBIPM: A Key to Success in Invasive Plant Management," this issue) can be used to reassess and refine future management activities. In the example presented here, we followed the steps of adaptive management by first setting a goal to impact ecological processes and initiate an ecosystem state change. Based on our site assessments, we developed and implemented a management plan for the demonstration study, and data were collected and analyzed over a number of years to reassess how the various replicated treatments impacted ecological processes. Through this process we recognized that transitioning from an invaded state to an alternative desired state requires both destabilizing ecological processes and structures that favor the undesired state while reinforcing those that foster resilience of the desired state. ${ }^{1,10}$ While we are cautiously optimistic that successful reductions in downy brome and establishment of perennial grasses provided the impetus to trigger a transition to a seeded range state (Fig. 1), more time is required to know for sure whether the targeted ecological processes (Fig. 2) were sufficiently altered. We can, however, speculate that if perennial grasses continue to be an important component of the ecosystem, they will exert biotic resistance to dispersal, reproduction, and litter production by downy brome. As the seeded range state is reinforced, it is also likely that the process of disturbance will be altered such that ecosystem recovery of foundational structural and functional attributes ${ }^{1}$ can be attained, such as recolonization of big sagebrush and black greasewood. However, in areas where perennial grasses fail to establish, it will be necessary to revisit the initial ecological principles used to guide the desired transition and/or adopt new principles to maintain the desired seeded range state and prevent transitioning back to invasive annual grass states (Fig. 1).

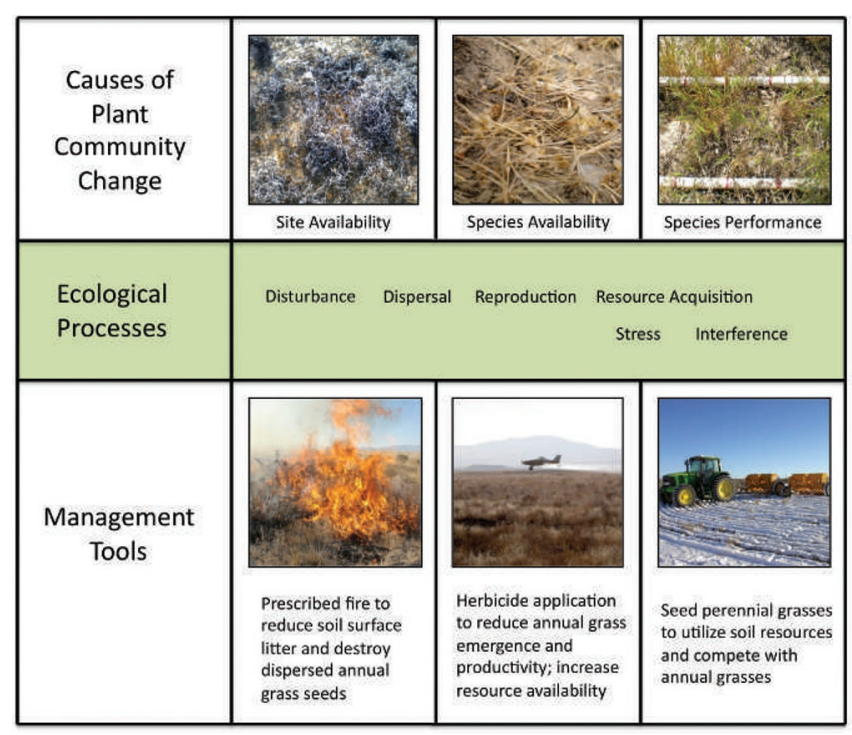

Figure 2. Linkages between causes of plant community change, ecological processes, and management tools developed for applying the EBIPM framework to salt desert shrub demonstration areas in Park Valley, Utah, USA.

\section{Conclusion}

The idea that humans, for good or bad, can change ecosystems is a central paradigm of land management. However, the complexity of ecological systems makes it difficult to envision how management activities can instigate sustainable changes to an invaded ecosystem state. Sustainable in this context would not only entail triggering a transition to an alternative state, but also include ongoing management to insure the ecosystem does not return to the invaded state. The EBIPM framework provides an effective procedure to identify ecological processes in need of repair and target them with effective management. Our application of the EBIPM framework suggests that sites will remain in an invasive annual grass state unless multiple ecological processes are simultaneously altered with appropriate tools and management strategies.

\section{Acknowledgment}

We thank Ken Spackman and Royce Larsen of Park Valley, Utah, who provided access to the private lands where the EBIPM framework was adopted.

\section{References}

1. Herrick, J. E., G. E. Schuman, and A. Rango. 2006. Monitoring ecological processes for restoration projects. Journal for Nature Conservation 14:161-171.

2. Morris, L. R., T. A. Monaco, C. A. Call, R. L. Sheley, and M. RALPHS. 2011. Implementing ecologically based invasive plant management: lessons from a century of demonstration projects in Park Valley, Utah. Rangelands 33(2):2-9.

3. Pyke, D. A., J. E. Herrick, P. Shaver, and M. Pellant. 2002. Rangeland health attributes and indicators for qualitative assessment. Journal of Range Management 55:584-597. 
4. Bestelmeyer, B. T., A. J. Tugel, G. L. Peacock, D. G. Robinett, P. L. Shaver, J. R. Brown, J. E. Herrick, H. Sanchez, and K. M. Havstad. 2009. State and transition models for heterogeneous landscapes: a strategy for development and application. Rangeland Ecology $\Xi^{\circ}$ Management 62:1-15.

5. Hirsch, M. C. 2011. Process-based management of downy brome in salt desert shrublands: Assessing pre- and postrehabilitation soil and vegetation attributes [master's thesis]. Logan, UT, USA: Utah State University. 138 p. Available at: http://digitalcommons.usu.edu/etd/1032. Accessed 29 September 2012.

6. Fowers, B. 2011. Ecologically-based manipulation practices for managing Bromus tectorum-infested rangelands [master's thesis]. Logan, UT, USA: Utah State University. 105 p. Available at: http:// digitalcommons.usu.edu/etd/1019. Accessed 29 September 2012.

7. Sheley, R. L., J.J.James, E. A. Vasquez, and T.J. Svejcar. 2011. Using Rangeland Health Assessment to inform successional management. Invasive Plant Science E Management 4:356-367.

8. Pickett, S. T. A., S. L. Collins, and J. J. Armenso. 1987. Models, mechanisms, and pathways of succession. Botanical Review 53:335-371.
9. James, J. J., B. S. Smith, E. A. Vasquez, and R. L. Sheley. 2010. Principles for ecologically based invasive plant management. Invasive Plant Science E Management 3:229-239.

10. Briske, D. D., B. T. Bestelmeyer, T. K. Stringham, and P. L. Shaver. 2008. Recommendations for development of resilience-based state-and-transition models. Rangeland Ecology E० Management 61:359-367.

Authors are Ecologist, USDA-ARS Forage and Range Research Laboratory, Utab State University, Logan, UT 84322, USA, tom.monaco@ars.usda.gov (Monaco); Professor, Wildland Resources Dept, Utah State University, Logan, UT 84322, USA (Call); Graduate Research Assistant, Dept of Rangeland Ecology and Management, Oregon State University, Corvallis, OR, 97331, USA (Hirsch); and Graduate Research Assistant, Dept of Plant Sciences, University of Wyoming, Laramie, WY 82071, USA (Fowers). Funding to support authors and the research summarized in this article was provided by the USDA-ARS AreaWide Pest Management Program for Annual Grasses in the Great Basin Ecosystem. 